Instructions for authors, subscriptions and further details:

$\underline{\text { http://ijelm.hipatiapress.com }}$

\title{
School Principals in Spain: an Unstable Professional Identity
}

\author{
Maximiliano Ritacco Real ${ }^{1}$ \\ Antonio Bolívar Botía ${ }^{1}$
}

1) Universidad de Granada. Spain

Date of publication: January $16^{\text {th }}, 2017$

Edition period: January 2018-July 2018

To cite this article: Ritacco, M. \& Bolívar, A (2018). School principals in Spain: an unstable identity. IJELM, 6(1), 18-39. doi: 10.17853/ijelm.2018.2110

To link this article: http://dx.doi.org/10.17583/ijelm.2018.2110

PLEASE SCROLL DOWN FOR ARTICLE

The terms and conditions of use are related to the Open Journal System and to Creative Commons Attribution License (CC-BY). 


\section{School Principals in Spain: an Unstable Professional Identity}

\author{
Maximiliano Ritacco Real \\ University of Granada
}

\author{
Antonio Bolívar Botía \\ University of Granada
}

\section{Abstract}

The article proposes an emerging approach in research on school leadership, within the framework of the "International Successful School Principalship Project (ISSPP)", where one of the three key research strands is "Principals' identities". It formulates, first, the theoretical framework for the professional identity from a narrative approach, linked -at the same time- to the practice of leadership, as an interactive relationship with the other members of the school. Successful leadership practices depend to a large degree on strong principals' identities. Second, it analyzes the biographical interviews of 15 school principals, through a process of structuring and categorizing the data collected, applying content analysis. The dimension of the principals' identities emerges in different categories: a) Personal identity; b) Professional identity (internal perspective); c) Professional identity (external perspective); d) Social identity; e) Professionalization; [and] d) Dual identity. Finally, the results are discussed, and lines are proposed to articulate and strengthen the identity of school principals in Spain.

Keywords: School Principals, Professional Identity, Narrative Research, Successful school. 


\section{Directores Escolares en España: una Identidad Profesional Inestable}

Maximiliano Ritacco Real Universidad de Granada

\author{
Antonio Bolívar Botía \\ Universidad de Granada
}

\section{Resumen}

El artículo propone un nuevo enfoque en la investigación sobre el liderazgo escolar dentro del marco del "Proyecto Internacional de directores de escuela exitosos (ISSPP)", donde uno de los tres ejes principales de investigación es "identidades de los directivos escolares". Se formula, en primer lugar, el marco teórico para la identidad profesional desde un enfoque narrativo, ligado -al mismo tiempo- a la práctica de la dirección, como una relación interactiva con los demás miembros de la escuela. En este sentido, se entiende que las prácticas de un liderazgo de éxito dependen en gran medida de una fuerte identidad de los directores. En segundo lugar, se analizan las entrevistas biográficas de 15 directores de las escuelas públicas, a través de un proceso de estructuración y categorización de los datos recogidos mediante la aplicación de análisis de contenido. La dimensión de las identidades de los directores surge en diferentes categorías: a) Identidad personal; b) Identidad profesional (perspectiva interna); c) Identidad profesional (perspectiva externa); d) Identidad Social; e) Profesionalización, [y] d) Doble identidad. Por último, los resultados se discuten y se proponen líneas de articular y fortalecer la identidad de los directores de escuelas en España.

Palabras clave: Directores de escuela, identidad profesional, investigación narrativa, escuelas exitosas. 

W ithin the framework of the European Union, Spain and Portugal shared (until 2008) a unique type of school leadership: the principal is a colleague chosen by his or her co-workers. Thus, the professional identity undergoes a transformation as it passes through a provisional trajectory that includes "acting as" or "being" the principal (identity as principal), later returning to the role of teacher, and then, in time, possibly to principal (4-8 years) again. Added to the "dual identity" (teacher/principal) are other duplicities: manager/leader, representative of the administration/colleague; person in charge of carrying out the regulations and the primum inter parents -representative of teachers- (Viñao, 2004).

This particular situation involving access to and discontinuity of the professional career, as mentioned above, becomes a relevant study topic from a biographical-narrative perspective, as employed in other studies (Bolívar et al., 2001; Bolívar, 2002; Abrahão \& Bolívar, 2014). Similar to the situation in France (Duchauffour, 2013; Pelletier, 2017), the principal in Spain presents an ambivalence in his/her functions: being principal and teacher at the same time, along with the "dual identity of transition" that has to take place: from teacher to head of the teaching establishment. This transition is rarely supported by the appropriate training. This situation of identity changes throughout the career is one of the main objectives of our study. As pointed out by Lumby and English (2009: 102), "rarely has the much more complex mutuality of multiple identities construction and the significance to leadership and its development been researched" (p. 102).

Thus, the identity is constructed in a process and a space (relational) that is, at the same time, a subjective construction and a social inscription (Dubar, 2010). It is common, therefore, to distinguish two dimensions: "identity for the self" and "identity for others" (Dubar, 1992; Ricoeur, 1992). Professional identities are established as a reciprocal transition (objective and subjective) between the attributed identity for others and the assumed identity. Both are binding, as they are the result of a long socialization process, with three interacting factors emerging (Day, Stobart et al., 2006; Whiteman et al., 2015): sociocultural, work context, and personal factors. As in the case of the teachers, the "principals' identities are constructed from and affected by the emotional influences of self, role and work context" (Crow, Day \& Möller, 2017: 269). The professional identities of the school leadership, like those of the teachers, are composed of interactions among personal, professional, and situational dimensions (Carroll \& Levy, 2010). 
From this perspective (identity), what "the principal" is will depend on how he/she is recognized by others and, above all, by his/her colleagues. The relevance of "oneself" in the principal, as pointed out by Ricoeur (1992), would not be such without "another" who recognizes his/her autonomy and decision-making capacity. Therefore, the principal's autonomy and identity, paradoxically, depend on others, given that they require their recognition and acceptance.

In the current times of individualization and deinstitutionalization (Dubet, 2001), characteristic of the late modern age (Giddens, 1991), the rules of the game have changed, re-establishing the essential aspects of the professional identity, the commitment, and daily practice (Bauman, 2000). These practices inevitably have an impact on the professional identity (Beck \& Beck-Gernsheim, 2001), and they are an analytical indicator of the practices (dynamics) teachers adopt to construct their lives and address their work.

It is worthwhile, then, to study, from the voices of the principals-teachers, how they experience these conditions (duplicity, continuity, etc.) in terms of identity, in their professionalization and throughout their careers (Beijaard, Meijer \& Verloop, 2004; Gohier, 2007). In our analysis, we are concerned with "disentangling the complex and situated interactions' between principals' thinking about themselves and the particular context they have to work in" (Kelchtermans et al., 2011: 94).

\section{Theoretical Framework}

The concept of identity is complex because it is not an objective reality, but rather a discursive and mental construction that individuals use to express a certain way of seeing themselves and feeling in relation to their representation and practice spaces (Freeman, 1995; Burke \& Stets, 2009). As we defined in a study on the topic (Bolívar \& Domingo, 2006), we understand the professional identity from an interactionist conceptualization of the profession associated with the Chicago School tradition and far from the functionalist way of viewing the professions. From a post-modern constructivist approach - compared to a substantialist, stable or linear perspective of identity - the multiplicity and discontinuity of the professional identity have been highlighted, as well as its social nature (Akkerman \& Meijer, 2011; Sugrue, 2015). This dialogic approach to the self, experienced as multiple, is not the same as the identity duplicity in 
school leadership established institutionally in Spain (the principal, after 48 years, becomes a teacher again). Along with it, the principal can experience, at the level of personal identity, the characterizations of the current dynamics. We can say that the debate on the question, based on Day, Kington et al., (2006), is whether the "situational identity" (temporarily occupying the principal's job) becomes (or not) a stable professional identity.

The context where the action takes place includes the definition of oneself and others (Ricoeur, 1992). This axis synchronizes while defining the situation, linking the context to the action (e.g., being the principal), without forgetting that, diachronically, the subject has a life and professional trajectory. As Dubar points out (2010): "among the 'official' definitions, attributed by another and the 'subjective' identifications, claimed for oneself and submitted to the recognition of the other, many combinations are possible" (preface to $4^{\text {th }} \mathrm{ed}$.)

Therefore, the objective of a sociological approach to the identities is to elucidate the forms of socially relevant identification in a sphere of determined action, which Dubar (2010) called 'identity forms'. In the arena between these two attributions of identity (convergence/divergence) lies the "identity form" acquired by a professional group (Dubar, 1992). For these reasons, the professional identity is established through personal experience and the recognized role (colleagues) in a common, shared space (individual- socio/professional-institution setting).

In this regard, a series of concepts can shed light on the phenomenon of the (re) construction of the identities. Initially, the professional identity can be understood as (Day \& Gu 2014): "how teachers regard themselves in relation to the community of teachers to which they belong. We include in this, the teachers' personal identity" (p. 55).

And at the same time, through role identity (Day \& Gu 2014): "how teachers see themselves in the particular role they play as members of the senior leadership team." (p. 55)

It should be clarified that roles are usually relatively stable, whereas the identities tend to vary, depending on negotiations with others and contexts. People can occupy different roles and feel that they have the same identity or, by contrast, many identities when taking on different roles. In any case, as Scribner and Crow (2012) state: "Identity provides motivation to take on and enact a role" (p. 246). 
Finally, the personal factor is incorporated. As the professional practice is mediated by the personal, it has been shown that there is an inevitable interrelation between the professional identity and the personal identity. As Day \& Kington (2008) warned: "Professional identity should not confused with role. Identity is the way we make sense of ourselves to ourselves and the image of ourselves that we present to others" (p. 9).

These aspects tell us that one can have the role of principal, but still feel mainly like a teacher (therefore, without the identity of the principal), as in the case of the Spanish principal who, due to being named by the Administration, is highly susceptible to wanting to return to the role of teacher. Likewise, there are cases where the role identifies temporarily with the identity: feeling like a teacher while being one, and identifying oneself as a principal when occupying that role. Roles and identities, in the Spanish case, in reality, do not identify with each other.

Referring to the teaching profession, Zabalza and Zabalza Cerdeiriña (2012) talked about the difference between "being" and "acting" in professional practice. Applying this to the school principal, being or acting as principal is quite different from feeling like a principal, experiencing it as an identity and becoming involved in this experience in an intense and committed way. In a similar way, in a specific study on the topic, Fernández (2011) referred to:

-being- the principal and its relations with -acting- as the leader, with the birth and development of his/her professional identity in a context of constant change" [in this way] the professional identity of the principal is incorporated into the way he/she experiences his/her personal identity and, as he/she is a teacher, his/her teaching identity (p. 26-29).

Thus, the complexity of the "Spanish case" is framed in the teacherprincipal-teacher professional transition, in which the actors experience an identity interference that affects the image of themselves as professionals and their relationship with others. These professional transitions, according to Balleux and Perez-Roux (2013), can be defined as:"a space/time of passage inscribed in the heart of a change, accepted or not, appropriate or not, and that requires the individual to use adaptation strategies to better manage elements of rupture and (re) construction of continuities" (p. 100). 
In this case, the professional transitions give rise to constant recompositions of identity that deserve to be analyzed. In the next section, we examine those methodological aspects that have been developed to analyze and investigate how the duplicity and discontinuity of the "Spanish model" impact the identity of school principals.

\section{Methodology}

The appropriate research design is framed within the qualitative approach, through semi-structured interviews (Brooks \& Normore, 2015). Likewise, a set of methodological decisions established the guidelines before the field study: a) Consider the weight of the discourse as the source of information; b) consider a chronological and historical perspective on the perceptions and opinions of the intervening subjects; c) apply content analysis as the technique for the methodological process (Wertz, Charmaz \& McMullen, 2011) [and] d) apply grounded theory as the basis for the construction of emerging knowledge (Strauss \& Corbin, 1998).

The identity is primarily narrative, as Ricoeur (1992) highlighted: "the narrative constructs the identity of the character, what can be called his or her narrative identity, in constructing that of the story told. It is the identity of the story that makes the identity of the character" (p. 147). In a similar way, Giddens (1991: 54) stated that "a person's identity is not to be found in behavior or - as important as this is - in the reactions of others, but rather in the capacity to keep a particular narrative going". If the identity is expressed through a narrative, narrative-biographical interviews make it possible for principals to express, in response to questions, their ways of seeing and interpreting their experiences: "how school principals experience their jobs, how they interpret their positions, what they understand about what they do, and what they know and do not know [...]. Through interactions and what the school principals say they are doing or not doing, they are making visible who they are or who they are becoming." (Crow, Day \& Möller, 2017: 271-2). Thus, biographical interviews are an appropriate instrument to make the professional identity emerge. 


\section{Selection criteria and distribution of key informants}

Fifteen principals were selected who had to have ...: a) held the position of principal for a minimum of 4 years; $\mathrm{b}$ ) been part of educational improvement processes; [and] c) had professional experience in terms of innovation.

With regard to the selection of the schools, the criteria were: a) to have a minimum of 15 secondary schools in the province of Granada (Andalucía); b) their geographical location, (five in the city center, five in suburbs of the metropolitan area, and five in surrounding areas and regions); c) the socioeconomic and cultural index -ISEC- provided by the Board of education of the Council of Andalusia (five high SECI, five medium SECI, five low SECI); d) the educational offering of the schools (plans and programs); and e) being financed by public funds.

\section{Data collection and processing techniques}

For the methodological design, an in-depth biographical interview guide was established that integrated the following thematic areas related to the school principal: a) the development of leadership; b) the professional integration processes; c) their functions; d) the impact of their work on the students' learning results; [and] implicitly, the impact on their professional, personal, and social identities, etc.

\section{Analytic procedure and categorization of the data}

The reduction of the data was performed inductively based on content analysis (Strauss \& Corbin, 1998; Wertz, et al., 2011). Their categorization and structuring were begun through the analysis of the information. First, the data were extracted from the information sources and organized in recording units (RU), which were successively turned into indicators (I). Continuing with the data reduction, after a "first round", the indicators (I) managed to make up a set of pre-categories. With a low level of specification, the emerging pre-categories could be organized into groups. Later, a "second round" allowed the reorganization of the indicators (I) into a series of consolidated emerging categories. 


\section{The emerging categories}

First, as other studies point out, "principals have multiple identities framed in personal, situated and professional perspectives and narratives" (Crow, Day \& Moller, 2017: 274).

The results of the study refer to the following emerging categories: a) Personal identity; b) Professional identity (internal perspective); c) Professional identity (external perspective); d) Social identity; e) Professionalization; [and] d) Dual identity.

Based on the fragments extracted from the testimonies of the interviewees, in the next section each of the emerging categories in the study will be developed

\section{Results}

In this section, we present the results of the study, accompanied by the fragments extracted from the interviews carried out with the school principals. These fragments, by representing the units of meaning stemming from the discourse analysis, are the basic empirical content in the emerging sub-categories.

\section{Personal identity}

If As defined by Demazière and Dubar (1997, p. 304), identity is: "a process of construction and recognition of a definition of whether it is satisfactory for oneself while being validated by the institutions in which one is socially inscribed and framed".

However, in another context, the principal recognizes him/herself as anti-authoritarian because he/she feels the need to create a good school atmosphere, which will have an impact on the teaching:

when you use a very authoritarian leadership model, very organized, very pyramidal, in which you say what is to be done and they have to do what you say; when you use this type of model, my experience tells me that the personal relationships decline a lot, and in the end the teaching staff, who are the most important agents and those who 
have to carry the weight of the education, this harms them a lot at a human and professional level.

In this way, according to another principal, you manage to involve the staff: "then later we extend it to the rest of the school community... you involve people little by little... then the degree of involvement is good".

\section{Professional identity (internal perspective)}

If Playing a leadership role means having some goals and objectives that contribute to achieving the school's desirable objectives and involving others in pursuing them. In this line of pedagogical leadership, one of the interviewees understands that his/her mission is to be the core generator of proposals: "one of my functions is to guide, channel, take proposals and, based on them, without starting from 0, create". Another points out, "the initiative of "we are going to do" arises from the leadership team, generally, and later many are involved, but this initiative stems, in $90 \%$ of the cases, from the principal".

$\mathrm{He} /$ she is usually recognized as the axis of the initiatives and model:

we are always going forward and pulling a lot from the leadership team by example, and it seems like if you take a step, others take it too; it is very difficult to tell someone to take a step if they haven't seen you do it.

Some of the principals interviewed recognize, in a mediated or indirect way, that they contribute to improving the learning results, whether by coordinating, organizing, or creating a climate of confidence and coexistence: "to create a good work atmosphere, we have to improve other areas and, indirectly, coordinate with everything else; that is where our work lies".

Along the same lines, another principal recognizes, in the same indirect way, that he/she is a factor in improving the students' learning results:

the principal is one of the key factors, indirectly, and I've said this many times, I am always a behind them to a certain extent, but with 
the purpose of contributing to improving academic performance and giving quality to our students

The principals understand that their main job is to become mediators, coordinators or directors: "we measure, coordinate, propose, encourage, guide; that is, I am someone who wants to help to look for the path".

In other cases, they see themselves as managers of a human team and resources in order to improve and develop the students: "what the principal does is manage a human team, resources, means, but his/her only end is to improve the students in terms of attitude, behavior, performance, and to do so, we need everyone's collaboration ...".

In other cases, they highlight that:"as the principal, what you do is a little of coordinating this and that and bringing out what is valuable and putting each one to work in his or her place".

In any case, the main task is to achieve cohesion in the teachers' work: "my objective has always been for everyone to move in the same direction, agree on projects, lines of work, mechanisms, try to work together, and for people to believe in it and move in the same direction."

\section{Professional identity (external perspective)}

Autonomy requires, as a flip side, responsibility in using it. Thus, one principal says: "There can be no autonomy without being accountable because I manage a budget of public money, and I am aware of this".

Normally, this accountability is done to satisfy the educational inspection: "we have periodic meetings in which we try to justify these results, and so these diligences that the administration itself indicates to us clearly must be responded to".

Another principal claims that the Leadership Project should be seen as a type of contract-program:

Now I am going to present a Leadership Project for 4 years, and if I make a commitment and the Board accepts me, I understand that the Board has to demand from me the objectives that I proposed, and they have to evaluate me based on them; but they have to facilitate the processes for this. 


\section{Social identity}

The identity is conceived as a subject's self-perception with regard to others, corresponding -in turn- to the recognition and approval of others. As such, it is not an essence, an attribute, or an intrinsic property of the subject, but rather it has an inter-subjective and relational nature. Claude Dubar (1992) pointed out that the social identity is the result of the articulation of these two socialization processes: 1) the attribution of the identity awarded through procedures and agents with which one interacts daily, in the form of "labelling"; and 2) the interiorizing of the identity by the individuals themselves. These two axes of biography and relation are combined to define, as mentioned above, what Dubar calls "identity forms", that is, forms of individuals' social identification in relation to others. The principal perceives that others see him/her socially as the one who solves problems and "puts out fires!"

The school principal thinks that, socially, he/she is identified as an agent who solves co-existence problems, teachers' difficult situations, and conflicts based on the here and now:

the conception is that the principal is often the person who puts out fires along the way; I have a problem... let the director come and solve it. But, all the work that goes on behind, all the administrative, pedagogical work of meetings, which is a lot, well this is not seen, and $\mathrm{I}$ think this is generalized [...]. In my school [another one comments] rather than being seen as an educational authority, I am the person who leads, but above all the person who has to resolve the questions, mediating, putting out fires along the way [...] If you haven't resolved it satisfactorily, well they can call into question your capability as principal

In many cases, they recognize the difficulty of being perceived as an "inspector" of the tasks their colleagues have to do and their reluctance to do so, in a negative image:

this is a very difficult and very tense situation because, in the end, it is about showing the teachers that their work hasn't produced results. 
People don't like to be told that "this is not okay" or "it can be improved.

In many cases, they are perceived: “...as if we were part of the administration".

The school principal in Spain is in a "bottleneck" between the Administration that named him/her as its representative and his/her colleagues, who chose him/her to defend their interests (Montero, 2015). It is a sort of "captive" model, expressed well by this principal:

...sometimes we find ourselves between a rock and a hard place...given that they demand from us as principals and leadership teams a series of aspects that must function in the school, and we have to demand them from the rest of the staff, and sometimes this effort is not recognized. We are between the Administration and the school itself, and they see us as an extension of the administration, when in reality we are also with the teachers.

A principal must have a broad set of skills, but mainly he/she must practice educational leadership, that is, educational leadership in the teaching-learning processes developed in the school: "therefore, this type of pedagogical leadership is quite complex, adapted to people, and even more so to people who do not have specific training".

Thus, another principal mentions:"when they begin the job, the principals are administrative managers because they are not prepared and, later, with time, perhaps in their second term, is when they start to display everything they are capable of".

Without being sure of where professionalization should go, they demand training or a differentiated career path that precedes the teaching: "I think the principal, regardless of how it is done, is a professional career, without it being a different body, I'm not going to go into that, but a professional career differentiated from the teachers".

In any case, there is a demand for specific training:

if I had to present my candidacy for principal now, I would not do it, because obviously to be the principal of a school now, it means nothing that I've been in teaching for X years and that I've been a 
good teacher; I understand that without a preparatory masters where all these topics are addressed, one should not be named principal..

\section{Professionalization}

The professional teaching identity is characterized by the set of knowledge and competences that are necessary to practice the teaching profession and socially recognized as such. The general characteristics that identify a profession, in turn, are specified in what the professional teaching identity is, as something common to all teachers, but also the individual result of a particular construction, which is the case of Elementary or High School teachers."I am the principal and I am going to be the principal for 4 more years because the teachers agree with me", one states.

But principals cannot be mere representatives of the teachers; therefore, they demand professionalization. Continuous criticisms of the current selection system appear in the voices of the principals: "this choice, in theory, is tainted as long as the principal's training is measured by how much teaching experience you have or by merits that have nothing to do with school leadership".

In other cases, they refer to the fact that the selection made by the School Board may not be objective, depending on the micro-politics of the school: "at a School Board meeting, a teacher tells me that my performance has been bad because a few days earlier I criticized him/her".)"

\section{Dual and Unstable identity}

A colleague chosen by his/her colleagues produces a certain "captivity" between the demands of the administration, which require formal authority, and the tensions with the teaching staff, which he/she forms part of and will return to in the future. One principal expresses it in this way: "This is related to the conception of the leadership model in this country, a model that is quite institutionalized and politically manipulated; you are captive because it is a captive model".

A principal recognizes the identity complexity and alienation, which dilutes the authority: "the first thing it improves is this relationship that we have with our co-workers, and the fact that we continue to call them co- 
workers is quite curious, but I continue to be a "colleague of" any teacher; of course -in addition- I am the principal".

In the words of another principal, they experience a certain contradiction:"I am a representative of teachers, so that I was chosen to represent the teachers' leader, and -at the same time- tell the teachers what they have to do..., this is very complicated!".

More serious is the fact that this situation usually interferes with the exercise of pedagogical supervision for improvement: "we do not have the capacity to influence what each teacher does in his/her classroom because, returning to the previous topic, the principal and the leadership team are just passing through, and their authority is limited ..."

\section{Discussion}

The conjunction between the theoretical framework from the literature and the field accounts collected allows us to define a set of dimensions that, in this first analysis, have been shown to be adequate to describe our study object. Thus, the triangulation of life narratives can be a relevant strategy for understanding the emotional "geographies", the way principals subjectively experience their work, the conditions of satisfaction, and the diversity of their professional identities, in sum, the problems of school principals from another perspective. At the same time, their knowledge makes it possible to reimagine lines to increase their professionalization and identities, redesigning the work contexts in ways that can reaffirm the fragile identities.

The complexity of the Spanish school leadership model deserves to be analyzed from the question of the dual identity of school principals. The instability caused by duplicity is not only manifested in the complicated and simultaneous exercise of the "teacher-principal-teacher" role, but also in the tensions produced by occupying an intermediate position between the demands of the administration and the negotiations with their "colleagues". As they affirm Crowm Day \& Møller (2017: 271) "change of status, conditions of service, workplace influences and unanticipated personal events trigger such instability". This "crossroads" is worsened if we take into account the itinerary of entering and exiting -transient- the job, and its selection system, in many cases burdened by the corporation. The principals' identity in Spain, to a greater degree than that of the teachers, "is 
not always stable, at certain times or during certain life, career and organisational phases may be discontinuous, fragmented, and subject to turbulence and change in the continuing struggle to construct and sustain a stable identity" (Day, Kington et al., 2006: 613).

In this regard, stemming from the contradictions, the impact of the professional identity does not take long. The principals do not deny the loss of exercise of formal authority. In exchange, the development of sociopersonal skills is required in order to progressively achieve a type of "moral" authority that finds its limits in aspects of the school culture, reflected, for example, in the pedagogical supervision.

Without remedying these questions, the professional identity of the principals defines an identity profile in a series of postures. They recognize themselves as core generators of proposals and initiatives, coordinators who organize human resources, mediators of conflicts, agents for cohesion, and creators of a positive work climate, all of which are merely the expression of a set of identity forms that exceed the formal role and lie within the limited margins of the "captive model".

In any case, the professionalization process of school principals is still pending. The state of the question does not reside in whether there is more or less training, but rather in what frame and/or coordinates it is inscribed. In this regard, there is no doubt that the complex questions will have to be thoroughly reviewed in order to achieve the development and consolidation of a professional identity of principals at the level of school leadership for educational improvement.

\section{References}

Abrahão, M. H. \& Bolívar, A. (Orgs.) (2014). La investigación (auto)biográfica en educación. Miradas cruzadas entre Brasil y España. Granada y Porto Alegre: Editorial de la Universidad de Granada y Editora da Pontifícia Universidade Católica do Rio Grande do Sul (EdiPUCRS).

Akkerman, S. F., \& Meijer, P. C. (2011). A dialogical approach to conceptualizing teacher identity. Teaching and Teacher Education, 27 (2), 308-319. DOI 10.1016/j.tate.2010.08.013

Balleux, A., Perez-Roux, T. (2013). Transitions professionnelles. Recherche \& formation, 74, 101-114. DOI 
Bauman, Z. (2000). The individualized society. London: Polity Press. Beck, U. \& Beck-Gernsheim, E. (2001). Individualization: Institutionalized individualism and its social and political consequiences. London: Sage.

Beijaard, D., Meijer, P. C., \& Verloop, N. (2004). Reconsidering research on teachers' professional identity. Teacher and Teacher Education, 20 (2), 107-128. DOI:10.1016/j.tate.2003.07.001

Bolívar, A. (2002). “¿De nobis ipsis silemus?”: Epistemology of biographical-narrative research in education. Revista Electrónica de Investigación Educativa, 4 (1), 24 pp.

Bolivar, A. \& Domingo, J. (2006). The professional identity of secondary school teachers in Spain: Crisis and reconstruction. Theory and Research in Education, 4 (3), 339-355. DOI 10.1177/1477878506069105

Bolívar, A., Domingo, J. \& Fernández, M. (2001). La investigación biográfico-narrativa en educación. Enfoque y metodología. Madrid: La Muralla.

Brooks. J.S. \& Normore, A. H. (2015). Qualitative research and educational leadership. International Journal of Educational Management, 29 (7), 798- 806. DOI:10.1108/IJEM-06-2015-0083

Burke, P. J., \& Stets, J. E. (2009). Identity theory. New York, NY: Oxford University Press.

Carroll, B., \& Levy, L. (2010). Leadership development as identity construction. Management Communication Quarterly, 24(2), 211231. DOI: $10.1177 / 0893318909358725$

Crow, G.M. (2011). Professional identities: Developing leaders for interprofessional practice. In J. Forbes C. Watson (Eds.). The Transformation of Childrens Services: Examining and Debating the Complexities of Inter/professional working (pp. 92-104). London: Routledge.

Crow, G., Day, C. \& Møller, J. (2017): Framing research on school principals' identities, International Journal of Leadership in Education, 20 (3), 265-277. DOI: 10.1080/13603124.2015.1123299

Day, C., Stobart, G., Sammons, P., Kington, A., Gu, Q., Semees, R. \& Mujtaba, T. (2006): Variations in teachers' work, lives and effectiveness. DfES Research Report 743. London: HMSO. http://dera.ioe.ac.uk/6405/1/rr743.pdf

Day, C., Kington, A., Sammons, P., \& Stobart, G. (2006). The personal and 
professional selves of teachers: stable and unstable identities. British Educational Research Journal, 32(4), 601-616. DOI: 10.1080/01411920600775316

Day, C. \& Kington, A. (2008). Identity, well-being and effectiveness: the emotional contexts of teaching. Pedagogy, Culture \& Society, 16 (1), 7-23. DOI: 10.1080/14681360701877743

Day, C. \& Gu, Q. (2014). Resilient teachers, resilient schools. London: Routledge.

Demazière, D. \& Dubar, C. (1997). Analyser les entretiens biographiques. L'exemple des récits d'insertion, Paris, Nathan.

Dubar, C. (1992). Formes identitaires et socialisation professionnelle. Revue française de sociologie, 33 (4), 505-529. DOI: 10.2307/3322224

Dubar, C. (2010). La socialisation. Construction des identités sociales et professionnelles. 4th revised edition. Paris: Armand Colin.

Dubet, F. (2001). Le Declin de l'Institution. Paris: Seuil.

Duchauffour, H. (2013). Transition identitaire des directeurs d'école primaire. Trouble et crise de recrutement, conséquences d'une formation défaillante ? Recherche \& formation, 74, 87-100. DOI

Fernández, M.L. (2011). Dirección e identidad professional. El ser o el estar en la dirección. Organización y Gestión educativa, 19 (2),25-29. DOI

Freeman, D. (1995). Asking "good" questions: Perspectives from qualitative research on practice, knowledge, and understanding in teacher education. TESOL Quarterly, 29 (3), 581-585. DOI $10.2307 / 3588077$

Giddens, A. (1991). Modernity and self-identity. Self and society in the late modern age. Cambridge: Polity Press.

Gohier, C. (Dir.) (2007). Identités professionnelles d'acteurs de l'enseignement. Regards croisés. Québec: Presses de l'Université du Québec.

Kelchtermans, G., Piot, L., \& Ballet, K. (2011). The lucid loneliness of the gatekeeper: Exploring the emotional dimensions in principals' work lives. Oxford Review of Education, 37 (1), 93-108. DOI: 10.1080/03054985.2010.545192

Lumby, J. \& English, F. (2009). From simplicism to complexity in leadership identity and preparation: exploring the lineage and dark secrets. International Journal of Leadership in Education: Theory 
and Practice, 12 (2), 95-114. DOI: 10.1080/13603120802449678 Montero, P. (2015). ¡Está ardiendo una papelera! Diario de una directora de instituto. Barcelona: Península.

Pelletier, G. (2017). Devenir dirigeant en éducation: défi d'identité, défi de savoirs d'action. Revue Enseignement et recherche en administration de l'éducation (ERADE), 1 (1), 31-48.

Ricoeur, P. (1992). Oneself as Another. Chicago: University of Chicago Press.

Sugrue, C (2015).Unmasking School Leadership: A Longitudinal Life History of School Leaders. Dordrecht: Springer.

Scribner, S.P. \& Crow, G.M.(2012). Employing Professional Identities: Case Study of a High School Principal in a Reform Setting. Leadership and Policy in Schools, 11 (3), 243-274. DOI: 10.1177/1741143217714485

Strauss, A., \& Corbin, J. (1998). Basics of qualitative research: Grounded theory procedures and techniques (2nd ed.). Thousand Oaks: Sage Publications.

Viñao, A. (2004). La dirección escolar: un análisis genealógico-cultural. Educação (Porto Alegre), 27 (2), 367-415.

Wertz, F.J., Charmaz, K., \& McMullen, L. M. (2011). Five ways of doing qualitative analysis: Phenomenological psychology, grounded theory, discourse analysis, narrative research, and intuitive inquiry. New York: The Guilford Press.

Whiteman, R.S. Paredes-Scribner, S. \& M. Crow, G. (2015). Principal professional identity and the cultivation of trust in urban schools. In Khalifa, M., Arnold, N. W., Osanloo, F.A. \& Grant, M. C. (Eds), Handbook of Urban Educational Leadership (pp. 578 - 590). USA: Rowman \& Littlefield.

Zabalza, M.A. \& Zabalza Cerdeiriña, M.A. (2012). Profesores y profesión docente. Entre el "ser" y el "estar". Madrid: Narcea. 
Maximiliano Ritacco is Ph. D. and Assistant Professor at the Faculty of Educational Sciences of the University of Granada

Antonio Bolívar is Full Professor at the Faculty of Educational Sciences of the University of Granada...

Address: University of Granada. Faculty of Educational Sciences, Campus of Cartuja, 18071 Granada (Spain)

Email: ritacco@ugr.es, abolivar@ugr.es 